\title{
NASSELLA TUSSOCK
}

\author{
By W. F. LEONARD, Department of Agriculture, Blenheim
}

Much has been written about nassella tussock (Nassella trichotoma) and the purpose of this additional paper is to give as far as possible an upto-date account of the measures being taken in search of a satisfactory control of this important weed. As a background a description of the weed is provided along with some information on its history, distribution, and spread.

\section{HISTORY}

Nassella tussock is a native of South America, and as well as being firmly established in Australia and New Zealand it has been recorded in France and Scotland. Only since about 1940 has the tussock been recognised as a serious weed in this country, though it is known to have existed here for more than 50 years. Several modes of entry into New Zealand have been suggested. They include such agencies as ballast, packing, wool, and lucerne seed, but none has been clearly established as being responsible.

\section{DESCRIPTION}

Healy (1) has published a detailed botanical description of nassella tussock and the features listed here are taken from it. The plant is a perennial, when mature forming dense tussocks, with a deep fibrous root system, a basal diameter of up to 6in., and a height and spread of up to $25 \mathrm{in}$. The leaves are very narrow, tough, harsh when drawn through the fingers, light green and rigid in the young stages, and dull green and drooping at maturity. A profusion of seed heads is carried on long drooping flower stalks and these plus a purplish colour at the flowering stage are characteristic of nassella tussock.

The fruit or seed of which 100,000 may be produced by an average plant in one year is small, rough-coated, very hard, with a ring of silky hairs about the base and a terminal awn up to lin. in length. When the seed is mature the flower stalk becomes detached from the parent plant and while still containing considerable seed is readily carried by winds which blow regularly at that season.

Confusion of nassella tussock with indigenous tussocks was no doubt largely responsible for the delay in recognising the danger involved in its establishment. Silver tussock ( $P$ oa caespitosa) is readily distinguished by its comparatively broad and smooth leaves, but fescue tussock (Festuca novae zelandiae) often presents a problem in identification. The chief distinguishing features are that nassella has no auricles, while the bases of its leaves are whitish, densely packed, and swollen. Needlegrass (Stipa spp.) can be distinguished by its long hairs at the base of the leaf.

\section{DISTRIBUTION}

As far as is known nassella tussock in New Zealand is confined to the South Island and the major infestations are to be found in North Canterbury and Marlborough. A survey carried out in 1941 (2) revealed that about 110,000 acres were infested in North Canterbury and about 5000 acres were infested to some extent at least in Marlborough. A further 260,000 acres in North Canterbury were described as likely to become infested in the absence of control measures. No recent figures are available for comparison with those of North Canterbury, but some idea 
of the increase in the area of nassella may be gained from the fact that the heavily infested area in Marlborough has grown from 290 acres in 1941 to about 500 acres at the present time. Furthermore an area of 20 acres of dense tussock observed in the Amuri County in 1941 was reported (3) in 1954 to have increased to 300 acres.

The North Canterbury area is contained in the Amuri, Cheviot, Waipara, and Kowai Counties, while the principal Marlborough infestation lies in the Fairhall Valley.

Isolated areas of nassella tussock have also been located at Rangiora, Kaiapoi, Waimakariri River, Rakaia Gorge, Lower Rakaia, and on the Port Hills, and near the mouth of the Ashburton River.

\section{FACTORS INFLUENCING SPREAD}

1. Climate: The prevailing wind blows from the north-west during the fruiting season and not only desiccates hill faces lying across its path but constitutes an effective means of seed dispersal.

Heavy frosts are common during winter in the districts concerned but under these conditions nassella seems better able to grow and spread than the more useful species, even to the extent of regenerating and flowering in winter after burning.

Average rainfall in these districts varies from $24 \mathrm{in}$. to $40 \mathrm{in}$. per annum, but low summer rainfall along with high rates of evaporation are common to all. At this time annual species mature and longer-lived species are checked, leaving bare ground for the establishment of nassella tussock seedlings.

Low relative humidity favours nassella in relation to species with higher moisture demands and at the same time aids the dispersal by wind of seed heads.

2. Physical features: Where hill country is involved (and such is largely the case) the main ranges run north-east and south-west, thus exposing north-westerly faces to the sun. These faces also lie across the path of the seed-carrying north-westerly wind.

3. Soils: Nassella tussock thrives on a wide range of soil types which vary considerably in fertility. However, where soil moisture is maintained the denser ground cover which results is less favourable for the establishment of nassella plants.

4. Period of flowering: The main flowering period occurs in October and November, but the ability of the tussock to flower and set seed at any time of the year increases its powers of invasion.

5. Ease of dispersal: Not only is nassella tussock seed readily dispersed by wind, but the nature of the seed itself makes it eminently suited for spreading in a variety of ways. Such agencies as rivers, animals, implements, motor vehicles, railway rolling stock, farm produce, and man could well play a part in the spread of the weed within districts and from one area to other non-infested localities.

6. Management: Apart from the application of active control measures management vitally affects the spread of nassella tussock. The maintenance of a dense and vigorous pasture cover is the best insurance against the establishment and spread of the tussock. To this end overgrazing and excessive burning should be avoided, vermin such as rabbits and pigs should be controlled, and bare patches such as rabbit poisoning furrows and grubbed areas should be sown, while any practices designed to improve pasture density and vigour, for example, topdressing and oversowing, should be encouraged. 
CONTROL

When nassella tussock control is considered two aspects of the problem come to mind. The first is that scattered and light infestations should be dealt with as soon as possible, preferably before setting seed. The second is that where extensive control work is to be carried out on heavily infested areas, those blocks farthest inland and towards the north-west of the districts involved should be the first selected. Otherwise the blocks being treated may be subject to re-infestation by wind-borne seed.

During the past 10 years various methods of nassella tussock control have been employed and among them have been:-

1. Grubbing: With light infestations and confining already existing areas of tussock hand grubbing has played an important part. Farmers themselves can, in this way, contribute much in the battle towards eradication. Grubbing has, however, the disadvantage that unless useful species are sown and encouraged to grow on the grubbed land, nassella tussock will soon re-establish.

2 Cultivation: Cultivation where possible is the most satisfactory method of dealing with heavy infestations: Cultivation should be sufficient to ensure that no tussocks continue to grow, while the length of time which elapses before further cultivation is required for control will depend largely on the vigour of the sown pasture.

3. Afforestation: Trees may be planted in belts to act as a barrier against the spread of seed by wind, or they may be planted in blocks for the purpose of suppressing tussock growth. In view of the fact that growth conditions which favour nassella tussock invasion are very different from those suitable for forest trees afforestation can in the cirferent for areas in North Canterbury have been planted and some success has been achieved particularly with Pinus radiata

Attempts were made to introduce various trees and shrubs to tussockinfested areas by seed sowing; but were unsuccessful. In North Canterbury Pinus and Acacia seed were both broadcast and spot sown, while in Marlborough manuka (Leptosperum scoparium) and kanuka (Leptosperum ericoides) seed was spread over a nassella block without any lasting result.

4. Burning: Nassella tussock burns readily and with great heat Possibly because of its density at the base, however, nassella is not permanently damaged by burning. On the other hand indigenous tussocks and other useful species which may be present are soon killed by repeated burning which ultimately produces a pure stand of nassella tussock. Only for the control of seeding on heavy infestations or perhaps prior to topdressing and oversowing can burning be justified. Current trials with herbicides will probably obviate the need for any burning as a control measure.

5. Grazing: In its native South American habitat nassella tussock is said to be sensitive to overgrazing. However, in New Zealand with the exception of horses no stock relish the plant, though cattle may be induced to eat some mature tussock, while both cattle and sheep will graze young plants and fresh regrowth.

Trials were begun in Marlborough in 1950 and in North Canterbury in 1951 to test the usefulness of grazing in controlling heavily infested areas of nassella. These have shown that cattle, when confined on sufficiently subdivided blocks of tussock, are fairly efficient in preventing seeding. Their use for this purpose is not expected to become very widespread since large numbers are required and adequate subdivision is essential. Furthermore the long-term effect of concentrated cattle grazing on hill country may not be in the interests of soil conservation. 
Cattle have served a useful purpose in reducing the amount of seed produced by certain heavily infested areas, but they can be regarded only as a stop-gap until more satisfactory methods can be applied.

6. Spelling, topdressing, and oversowing: A number of trials have been conducted where spelling, topdressing, and oversowing were used in an effort to suppress nassella tussock. Where these trials were established on existing stands the rate of increase of tussock was reduced in one case, while some control of seed dispersal was achieved. Nevertheless no tussock mortality occurred.

Topdressing and oversowing following the destruction of existing nassella plants by spraying has on the other hand given very promising results. Details of one such trial are included in the following section on chemical methods of control.

7. Chemicals: Early trials seeking to control nassella with chemicals met with little success. In a paper presented at the 1954 Conference R. A. Milne described in detail trials which had been carried out up to that time in North Canterbury. Though some reference to North Canterbury trials will be made, this section will deal mainly with trials conducted in Marlborough.

Two trials were laid down on ploughable land in 1946. In one trial 2,4-D was applied as spray and dust but had no appreciable effect. The other trial involved the application of fertiliser to encourage grass and clover growth and possibly increase the palatability of the nassella tussock to stock. Inter-tussock spaces were more heavily grazed, but no control of tussock resulted.

Grazing and oversowing trials followed and in October 1951 the first trial with TCA was established. TCA at 251b., 50lb., and 100lb. per acre was applied to closely grazed and ungrazed tussock. After a year a further 25lb. of TCA per acre was applied and though seedlings which had established on bare patches were killed, no permanent damage was done to surviving tussocks. At the highest rate a kill of between 50 and 60 per cent. was secured, ranging down to 20 per cent. at the lightest rate. No difference was recorded between the closely grazed and the ungrazed plots.

A further trial was laid down in October 1952 in which TCA was applied to closely grazed nassella at the rate of $251 \mathrm{~b}$. and $50 \mathrm{lb}$. per acre The following autumn a further $251 \mathrm{~b}$. of TCA per acre was applied to all plots and a grass and clover mixture was surface sown after the first substantial rain. Very few tussocks were killed on any plot, with the result that sown species had little chance of establishment. In an effort to discover just how much TCA was required to kill mature nassella tussocks under the existing conditions parts of this trial were treated with $100 \mathrm{lb}$. and $200 \mathrm{lb}$. of TCA per acre in October 1953. Even at these high rates no more than about a 30 per cent. kill was achieved.

In view of the failure of TCA to give a satisfactory kill when applied at what was believed to be the optimum season, that is, the spring, a time of application trial was established in August 1953 using TCA at the rate of 1001b. and 2001b. per acre. These rates were applied monthly for a year and some very striking results were secured. Winter and spring applications resulted in almost complete regrowth of tussock at both rates, whereas late summer applications gave virtually a complete kill at both rates. Between these extremes lay plots treated in the late spring and late autumn where the $2001 \mathrm{~b}$. rate was completely effective, while the lighter rate killed only a proportion of the nassella plants present. The summer and autumn periods in question were not unusually wet.

In order to check the results just described a similar time of application trial was laid down in March 1955 using TCA at 501b. and 1001b. 


\section{TIME OF APPLICATION OF TCA \\ TO NASSELLA TUSSOCK 16/3/2937}

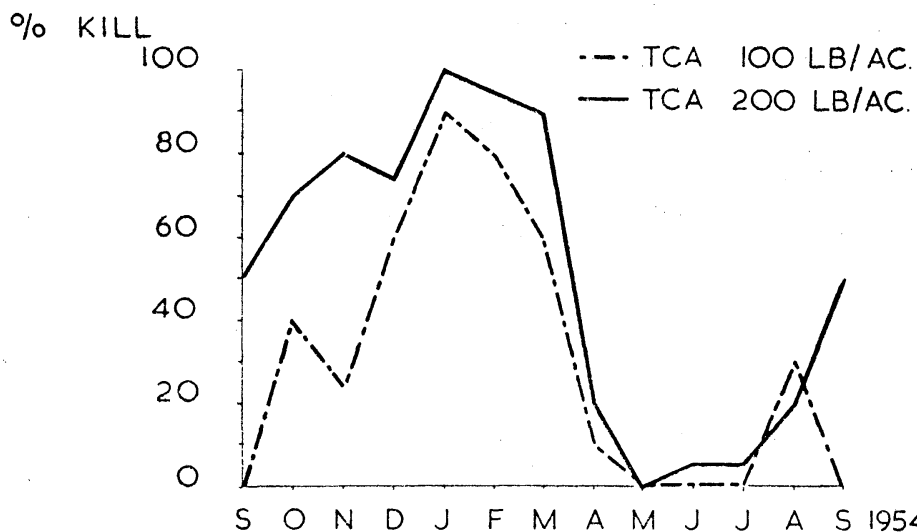

per acre and Dalapon at the same rates. In July of the same year an additional trial of the same design was begun involving this time Dalapon only at the rate of $201 \mathrm{~b}$. and $301 \mathrm{~b}$. per acre. Sufficient time has not yet elapsed to evaluate treatments applied in the later stages of these trials, but certain points have already emerged. On all plots where any conclusion regarding effectiveness can be drawn Dalapon has proved clearly superior to TCA at similar rates. In both trials with Dalapon the summer and autumn applications were among the last to be made. These months therefore cannot yet be evaluated with any certainty, but it is quite apparent that in the Marlborough district at least the winter and early spring periods should be avoided when applications of TCA and Dalapon to nassella are being made. It seems likely, however, that this "off season" may be considerably shorter where Dalapon is concerned than with TCA.

The lighter rates of Dalapon applied in the summer and autumn are showing promise and in view of the kill secured in a trial at Waipara North Canterbury, this material will probably prove very useful in nassella tussock control. In the Waipara trial Dalapon applied at 30lb. per acre in April 1955 gave a complete kill. TCA applied at the rate of $100 \mathrm{lb}$. and 2001b. per acre at the same time gave slightly inferior results.

After the poor results secured from over-sowing on dense nassella an area was treated with TCA at 2001b. per acre in February 1954 and the following month a topdressing and oversowing trial was established. Grasses and clovers were broadcast and fertiliser rates ranged from normal to very heavy amounts in order to find out whether at any cost, so to speak, a vigorous pasture cover could be established and maintained. Results have been most encouraging. In the early stages density and vigour of sown clover species were much greater on the plots treated with lime at 3 tons plus superphosphate at 10cwt. per acre, but after the first year the plots with lower rates had shown considerable improvement. Plots treated with lime at 1 ton per acre plus superphospate at $3 \mathrm{cwt}$. per acre now contained a dense and vigorous cover of white clover and lucerne, while those treated with superphosphate only at 3cwt. per acre are not greatly inferior. Seedling nassella tussock growth has so far 
been completely suppressed on the densely covered plots. Such a successful establishment of pasture species on a dry northerly face raises the question of whether the effect of TCA on the soil or soil organisms may under certain conditions aid pasture establishment. The fact that the summer and autumn following the laying down of the trial were very dry makes the results even more remarkable.

Since the destruction of scattered tussocks will be of importance long after major infestations have been controlled, trials on the "spot" treatment of such plants are now under way. Various rates of Dalapon are being used and the minimum amount of water required as a spreader is being determined.

8. Legislation: With the passing of the Nassella Tussock Act in 1946 two boards were set up, one for Marlborough and one for North Canterbury, for the purpose of controlling and eradicating nassella tussock. The boards encourage farmers to eradicate the weed, employ rangers for the inspection of properties, maintain grubbing gangs where possible, and distribute subsidies for fencing and tree planting for tussock control. Both boards are now treating considerable areas annually with TCA applied from the air. This work is still largely experimental in nature and is being done in some cases to control seeding, while in others complete destruction of the existing tussock is the aim. In Marlborough the Nassella Tussock Board itself controls the property where practically all the dense tussock is growing.

The Nassella Tussock Seed Regulations introduced in 1949 were designed to guard against the spread of nassella tussock as an impurity in small seeds. Grass and clover seed harvested within cerrtain areas is examined for nassella tussock seed and infested lines must be redressed to remove the impurity or, if this is not possible, be destroyed.

\section{SUMMARY}

The nassella tussock problem has reached its present proportions mainly through the belated recognition of its seriousness and the suitability of the plant itself to distribution by wind over a wide area.

Numerous methods of control have played and will continue to play important roles in confining and eradicating nassella infestations. The maintenance of a dense and vigorous sward is of prime importance in preventing infestation. The prevention of seed setting must be one of the first considerations, cattle grazing and spraying with herbicides having been used in this direction.

Grubbing has been of value in dealing with scattered tussocks, but will probably be largely superseded by "spot" spraying. Afforestation, particularly in waste areas, is effective, but repeated burning should be avoided.

Of the chemicals used so far TCA and Dalapon have been the most effective. The area of tussock being sprayed from the air is increasing rapidly and it appears likely that despite the expense herbicides will be required over many thousands of acres to control existing infestations. The encouragement of dense and vigorous pasture growth and the "spot" treatment of tussocks which appear, particularly on dry north-west faces, would then need to become part of routine management.

\section{REFERENCES}

1. A. J. Healy. "Nassella Tussock", Bulletin 91, Department of Scientific and

2. A. J. Healy and P. R. Barrer, "Report on the Survey of the Nassella Tussock Position in North Canterbury", Plant Research Bureau, No. 287, 1941 3. R. A. Milne, "Nassella Tussock Control". Proceedings of the Seventh New 


\section{DISCUSSION}

Q.-Have you had any experience with pelleted TCA in nassella tussock control?

A.-No, but granulated TCA has been used in North Canterbury with promising results. 